\title{
STUDI PEMANFAATAN KULIT KOPI ARABIKA (Coffee arabica L.) SEBAGAI MIKRO ORGANISME LOKAL (MOL)
}

\author{
A. Ita Juwita ${ }^{1}$, Arnida Mustafa ${ }^{2}$, Risna Tamrin ${ }^{3}$ \\ ${ }^{1,2,3}$ Program Studi Agroindustri, Politeknik Pertanian Negeri Pangkep \\ Email: ${ }^{1}$ ithachem01@gmail.com
}

\begin{abstract}
MOL (Mikro Organisme Lokal) is the result of local material decomposition with fermentation method. MOL contains macro and micro nutrients and microbial decomposers. The smaller coffee peel that will fermented, the faster MOL can be formed. To accelerate decomposition in MOL solution, it can be added food source of bacteria such as coconut water and brown sugar.

The purpose of this study was to study the process of making MOL from coffee peel, to analyze the content of nitrogen, phosphor, and potassium of MOL of coffee peel and to determine the effect of fermentation time on nitrogen, phosphor, and potassium contents of MOL that resulted.

This study was conducted with 4 (four) treatments, week 1, 2, 3 and 4 and 1 factor and using 2 times replicate. The parameter of testing used for making coffee peel as local microorganism are MOL volume, nitrogen, phosphor and potassium contents.

The result of study showed that the highest mol volume obtained in week 4 of $8.5 \mathrm{ml}$ and the lowest in week 1 of $5 \mathrm{ml}$. They were obtained from $500 \mathrm{~g}$ coffee peel. Determination of nitogen, phosphorus and potassium as a macro nutrients has been conducted. The result showed that the highest nitrogen was found to be $0,0039 \%$ in week 1,3 and 4 and the lowest in week 2 with percentage $0.034 \%$. Determine of phosphorus showed that the highest phosphor was obtained in week 2 wtih percentage $0.033 \%$ and the lowest in week 4 of $0.018 \%$, and the result of potassium analyze, the highest obtained in week 2 of $0.035 \%$ and the lowest in week 4 of $0.014 \%$.
\end{abstract}

Keywords: coffee peel, fermentation, local microorganism, nitrogen, phosphor, potassium.

\section{PENDAHULUAN}

Indonesia merupakan negara penghasil kopi ketiga di dunia setelah Brazil dan Vietnam. Pada tahun 2012 Indonesia mampu memproduksi paling sedikit 748 ribu ton atau $6,6 \%$ dari produk kopi dunia. Kopi ini dihasilkan dari perkebunan kopi yang luasnya mencapai 1,3 juta hektar (Hartono, 2013).

Berdasarkan banyaknya jumlah kopi yang ada, maka pengolahan kopi akan menghasilkan banyak limbah. Limbah buah kopi biasanya berupa daging buah yang secara fisik komposisi mencapai $48 \%$, terdiri dari kulit buah $42 \%$ dan kulit biji $6 \%$ (Zainuddin et al, 1995). Sementara menurut Simanihuruk et al. (2010), proporsi kulit kopi yang dihasilkan dalam pengolahan cukup besar, yaitu $40-45 \%$. Padahal, kandungan kulit kopi masih cukup bagus, yaitu protein kasar 10,4\%, serat kasar 17,2\% (Zainuddin et al., 1995).

Pemanfaatan limbah kopi hingga saat ini belum maksimal. Pengembangan perkebunan, khususnya kopi yang dilakukan saat ini secara tidak langsung juga akan menambah jumlah limbah kopi yang dihasilkan. Oleh karena itu, perlu sebuah terobosan baru guna mengolah limbah kopi agar dapat dimanfaatkan dan tidak terbuang sia-sia. Limbah kopi mengandung beberapa zat kimia beracun seperti alkaloid, tannin, dan polifenol. 
Dampak lingkungan berupa polusi organik limbah kopi yang paling berat adalah pada perairan di mana effluen kopi dikeluarkan. Substansi organik terlarut dalam air limbah secara amat lamban dengan menggunakan proses mikrobiologi dalam air yang membutuhkan oksigen dalam air. Karena terjadinya pengurangan oksigen terlarut, permintaan oksigen untuk menguraikan organik material melebihi ketersediaan oksigen sehingga menyebabkan kondisi anaerobik. Dampak sederhana yang ditimbulkan adalah bau busuk yang cepat muncul. Hal ini karena kulit kopi masih memiliki kadar air yang tinggi, yaitu 75-80\% (Simanihuruk et al., 2010) sehingga sangat mudah ditumbuhi oleh mikroba pembusuk, hal ini akan menggangu lingkungan sekitar jika dalam jumlah besar dapat mencemari udara.

Limbah padat dan cair yang dihasilkan dari tahapan pengolahan kopi basah sangat tinggi. Upaya pemanfaatan limbah pengolahan kopi baik dalam bentuk padat maupun cair menjadi produk yang memiliki nilai ekonomi lebih tinggi perlu dilakukan. Berdasarkan penelitian kulit kopi memiliki kandungan nutrisi yang tidak terlalu tinggi, oleh sebab itu perlu dilakukan langkahlangkah peningkatannya dengan cara fermentasi menggunakan Mikroorganisme Lokal.

Tujuan dari penelitian ini yaitu mempelajari proses pembuatan MOL (Mikroorganisme Lokal) dari kulit kopi, menganalisis kadar Nitrogen, Fosfor dan Kalium dari MOL (Mikroorganisme Lokal) kulit kopi, dan mengetahui pengaruh waktu fermentasi terhadap kadar Nitrogen, Fosfor, dan Kalium dari MOL (Mikroorganisme Lokal) yang dihasilkan.

\section{METODE PENELITIAN}

Penelitian pendahuluan dilakukan dengan dan tanpa proses blender atau penghancuran kulit kopi. Sedangkan penelitian utama dilakukan variasi waktu fermentasi.

\section{Prosedur Kerja}

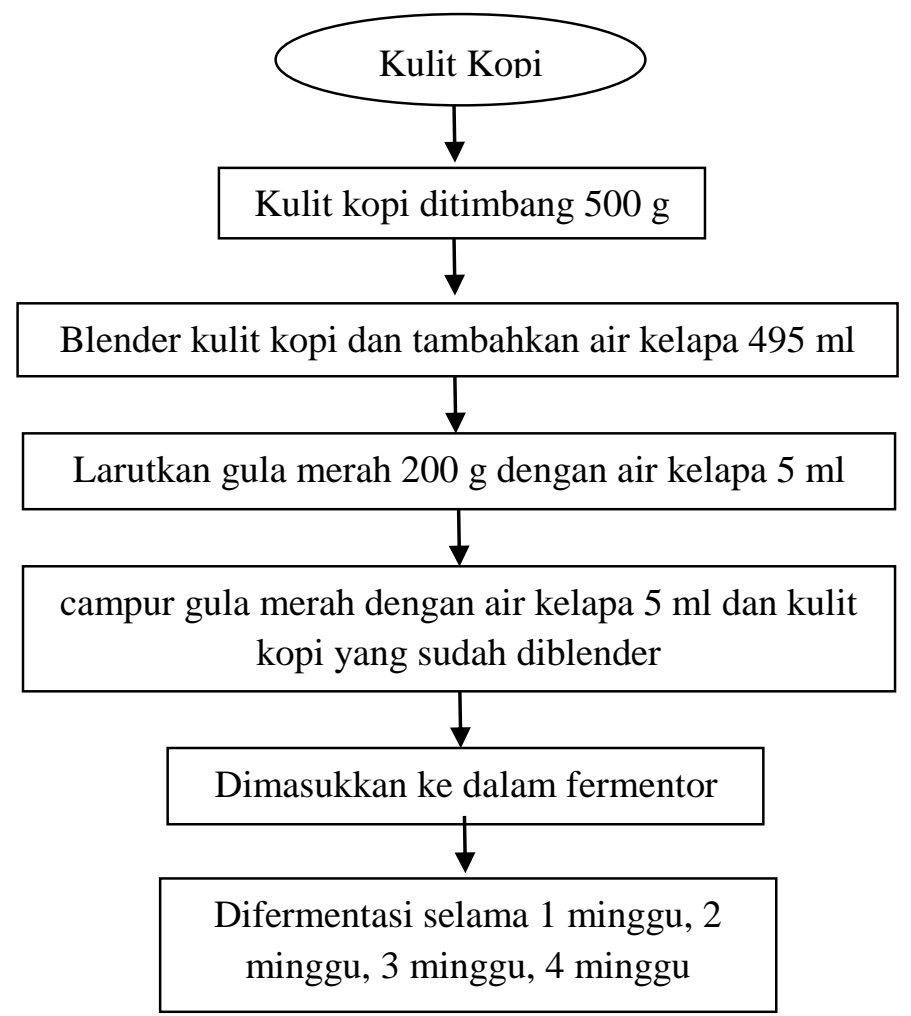

Gambar 1. Diagram alir penelitian utama pembuatan MOL kulit kopi 


\section{Analisa Kadar Nitrogen, Fosfor, dan} Kalium

Penetapan N-Total dilakukan dengan cara Semi-Mikro-Kjeldahl yang dimodifikasi (AOAC, 1970). Sedangkan penentuan fosfor, kalium dan natrium dilakukan dengan titrasi volumetri.

\section{HASIL DAN PEMBAHASAN}

\section{Penelitian Pendahuluan}

Hasil penelitian pendahuluan pada pembuatan mikroorganisme lokal (MOL) dari kulit kopi disajikan pada Tabel 1.

Tabel 1. Karakteristik MOL (mikroorganisme lokal) dengan perlakuan blender dengan proses penghancuran dan tanpa blender (tanpa penghancuran).

\begin{tabular}{ccc}
\hline Karakteristik & Tanpa Blender & Blender \\
\hline Aroma Alkohol & ++ & +++ \\
Gelembung & + & +++ \\
Tekstur & +++ & ++ \\
Cairan & ++ & +++ \\
Warna & + & ++
\end{tabular}

Keterangan:

$$
\begin{gathered}
+=\text { Kurang } \\
++=\text { Cukup } \\
+++=\text { Banyak }
\end{gathered}
$$

Berdasarkan Tabel 1 aroma alkohol yang dihasilkan pada blender dengan proses penghancuran lebih menyengat dibanding dengan tanpa blender yang tidak dihancurkan. Gelembung yang dihasilkan pada perlakuan blender menghasilkan banyak gelembung dibanding perlakuan tanpa menggunakan blender dan tekstur pada perlakuan tanpa blender kasar sedangkan tekstur pada perlakuan blender halus. Demikian pula dengan cairan yang dihasilkan pada kedua perlakuan. Pada perlakuan tanpa blender cairan yang dihasilkan lebih sedikit. Warna pada blender dengan penghancuran kuning kecoklatan dan terjadi perubahan morfologi berupa serasa-serasah halus tinggal sedikit, sedangkan pada tanpa blender berwarna coklat. Secara fisik pupuk cair yang baik menurut Hadisuwito (2012) adalah berwarna kuning kecoklatan dan bahan pembentuknya sudah membusuk. Dalam penelitian ini, peneliti membuat pupuk organik cair yang sering disebut dengan mikroorganisme lokal (MOL) dari limbah organik, yaitu kulit kopi.

Semakin busuk dan halus kulit kopi yang akan difermentasikan maka akan semakin cepat untuk terurai sehingga akan lebih cepat menjadi MOL. Untuk mempercepat penguraian di alam larutan MOL, maka ditambahkan sumber makanan bagi bakteri berupa air kelapa dan gula merah yang terdapat dalam larutan MOL. Hal ini sesuai dengan pendapat Djati Runggo (1985) yang menyatakan bahwa sumber makanan dapat berupa glukosa dan karbohidrat. Sumber makanan digunakan bakteri sebagai energi dalam dekomposer kulit kopi yang akan dijadikan MOL.

MOL yang dibuat pada penelitian pendahuluan ini membutuhkan waktu 2 minggu. Akan tetapi, semakin banyak bakteri di dalam larutan, maka akan semakin cepat juga dekomposer terjadi hingga menjadi MOL sehingga peran bakteri sangat dibutuhkan dalam pembuatan MOL.

Berdasarkan Tabel 1 maka dapat disimpulkan bahwa perlakuan terbaik adalah pada perlakuan penghancuran dengan menggunakan blender, dan selanjutnya prosedur inilah yang digunakan pada penelitian utama. 


\section{Pembuatan MOL dari kulit kopi}

Berdasarkan hasil penelitian pendahuluan diperoleh bahwa pembuatan mikroorganisme lokal dengan penghancuran merupakan perlakuan terbaik, adapun tahapan pada pembuatan mikroorganisme lokal yang dilakukan dengan penghancuran dimulai dengan tahapan penimbangan dilanjutkan dengan proses penghancuran. Tujuan dari proses penghancuran adalah untuk pengecilan ukuran. Pengecilan ukuran artinya membagibagi suatu bahan padatan menjadi bagianbagian yang lebih kecil (Smith, 1955).

Penambahan gula merah yang dilarutkan dengan air kelapa berfungsi sebagai substrat mikroorganisme lokal. Untuk mempercepat penguraian di dalam larutan MOL, maka ditambahkan sumber makanan bagi bakteri berupa air kelapa yang terdapat dalam larutan MOL. Hal ini sesuai dengan pendapat Djati Runggo (1985) yang menyatakan bahwa sumber makanan dapat berupa glukosa dan karbohidrat.sumber makanan digunakan bakteri sebagai energi dalam dekomposer kulit kopi yang akan dijasikan MOL.

Tahapan selanjutnya adalah tahapan fermentasi, pada tahapan ini semua bahan di masukkan kedalam fermentor dan dilakukan fermentasi dalam suasana anaerob. Hal ini sesuai dengan pendapat Hawab (2004) yang berpendapat bahwa hasil akhir reaksi fermentasi pada suasana anaerob adalah etanol, $\mathrm{CO}_{2}$ dan $\mathrm{H}_{2} \mathrm{O}$. Ngili (2009) juga menambahkan bahwa etanol, $\mathrm{CO}_{2}$ dan $\mathrm{H}_{2} \mathrm{O}$ dihasilkan dari proses pemecahan glukosa dalam proses fermentasi yang bersuasana anaerob.

Larutan MOL mengandung unsur hara makro, mikro, dan mengandung mikroorganisme yang berpotensi sebagai perombak bahan organik, perangsang pertumbuhan, dan agen pengendali hama dan penyakit tanaman sehingga baik digunakan sebagai dekomposer, pupuk hayati, dan pestisida organik (Purwasasmita, 2009). Faktor-faktor yang menentukan kualitas larutan MOL antara lain media fermentasi, kadar bahan baku atau substrat, bentuk dan sifat mikroorganisme yang aktif di dalam proses fermentasi, $\mathrm{pH}$, temperatur, lama fermentasi, dan rasio $\mathrm{C} / \mathrm{N}$ larutan $\mathrm{MOL}$ (Suriawiria,1996; Hidayat, 2006). Hubungan lama fermentasi dengan volume MOL kulit kopi dapat dilihat pada Gambar 1.

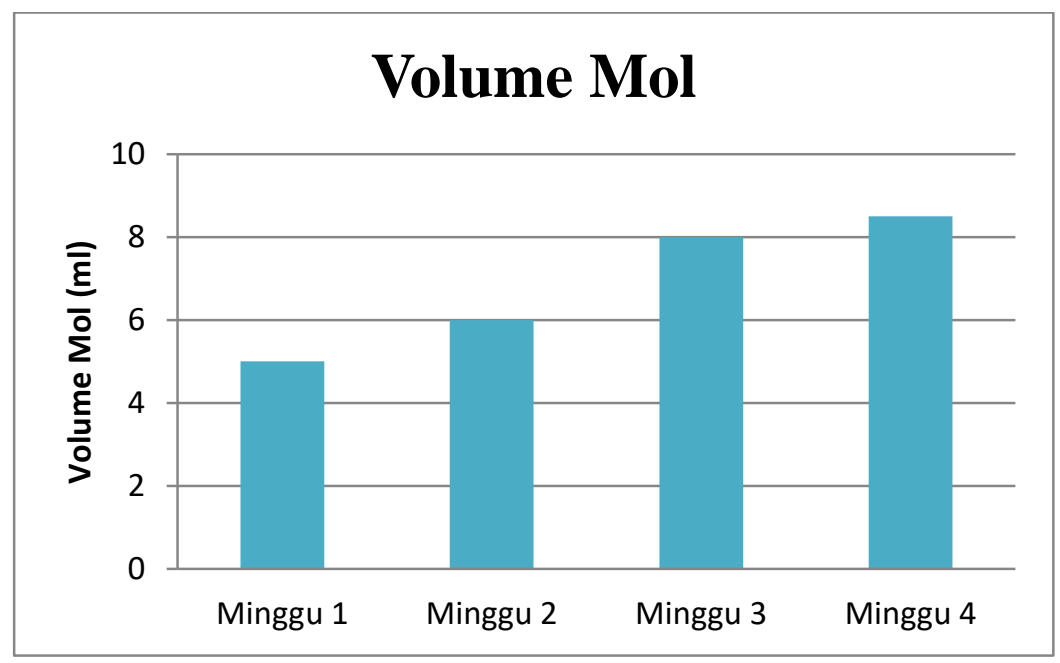

Gambar 1. Histogram volume MOL kulit kopi

Berdasarkan Gambar 1 volume MOL kulit kopi pada minggu 1 yaitu $5 \mathrm{ml}$ dan minggu 2 yaitu $6 \mathrm{ml}$, masih kurangnya volume MOL yang dihasilkan disebabkan karena belum sempurnanya fermentasi pada minggu 1 dan 2. Menurut Muchtadi (2010), fermentasi merupakan proses oksidasi anaerob karbohidrat menghasilkan alkohol dan asamasam. Gula jika difermentasi akan menghasilkan etanol, asam laktat, asam butirat, aseton, dan hidrogen. Sedangkan menurut Suhastyo (2011), pada proses fermentasi terjadi dekomposisi terhadap bentuk fisik padatan dan pembebasan 
sejumlah unsur penting dalam bentuk senyawa-senyawa kompleks maupun senyawa-senyawa sederhana ke dalam larutan fermentasi. Volume mol pada minggu 3 yaitu $8 \mathrm{ml}$ dan volume mol pada minggu 4 yaitu 8.5 $\mathrm{ml}$, hal ini menunjukkan bahwa semakin lama fermentasi maka volume larutan mol yang dihasilkan juga semakin meningkat

\section{Pengujian Kadar Nitrogen}

Unsur nitrogen merupakan salah satu unsur penyusun protein sebagai pembentuk jaringan dalam makhluk hidup, dan di dalam tanah unsur $\mathrm{N}$ sangat menentukan pertumbuhan tanaman (Sutanto, 200). Sebagian besar dari nitrogen total dalam air dapat terikat sebagai nitrogen organik, yaitu dalam bahan-bahan berprotein. Nitrogen diserap oleh akar tanaman dalam bentuk $\mathrm{NO}_{3}{ }^{-}$ (nitrat) dan $\mathrm{NH}_{4}{ }^{+}$(amonium). Nitrogen yang berasal dari bahan organik tertentu diperoleh melalui amonisasi-nitrifikasi (Mulyadi, 1994).

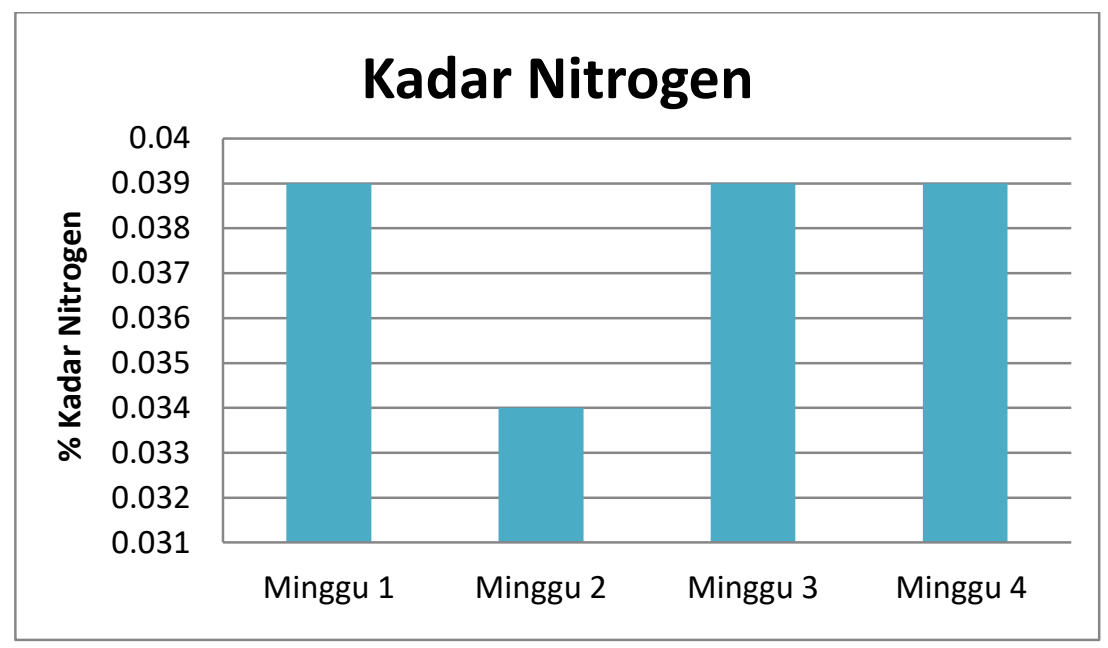

Gambar 2. Histogram pengujian kadar nitrogen (\%) pada mikroorganisme lokal kulit kopi

Berdasarkan Gambar 2 diperoleh bahwa perlakuan minggu 1 , minggu 3 , dan minggu 4 mengalami peningkatan yang sama yaitu 0.039 . Kadar nitrogen selama proses pembuatan pupuk cair cenderung meningkat, hal ini disebabkan adanya $\mathrm{N}$ sebagai produk penguraian protein dari proses dekomposisi. Peningkatan kadar nitrogen di akhir proses juga disebabkan adanya proses amonifikasi, yaitu proses pembentukan amonium dari bentuk teroksidasinya yaitu nitrit. (Andiyana, 2004).

Sedangkan pada minggu 2 terjadi penurunan, hal ini disebabkan karena nitrogen dalam oksigen bentuk amonia sebagai hasil dari dekomposisi bahan organik yang lepas ke udara. Tidak masuk secara merata pada tumpukan sehingga oksigen yang ada jumlahnya terbatas, sehingga mengakibatkan ammonia tidak dapat dirubah ke dalam bentuk nitrat. Nitrogen dapat hilang sebagai gas $\mathrm{NH}_{3}$, khususnya pada kondisi temperatur dan $\mathrm{pH}$ tinggi serta akibat pengadukan.

\section{Pengujian Kadar Fosfor}

Fosfor merupakan unsur hara yang terpenting bagi tumbuhan setelah nitrogen. Unsur ini merupakan bagian penting dari nukleoprotein inti sel yang mengendalikan pembelahan dan pertumbuhan sel, demikian pula untuk DNA yang membawa sifat-sifat keturunan organismpe hidup. Senyawa Fosfor juga mempunyai peranan dalam pembelahan sel, merangsang pertum-buhan awal pada akar, pemasakan buah, transport energi dalam sel, pembentukan buah dan produksi biji (Yulipriyanto, 2010). 


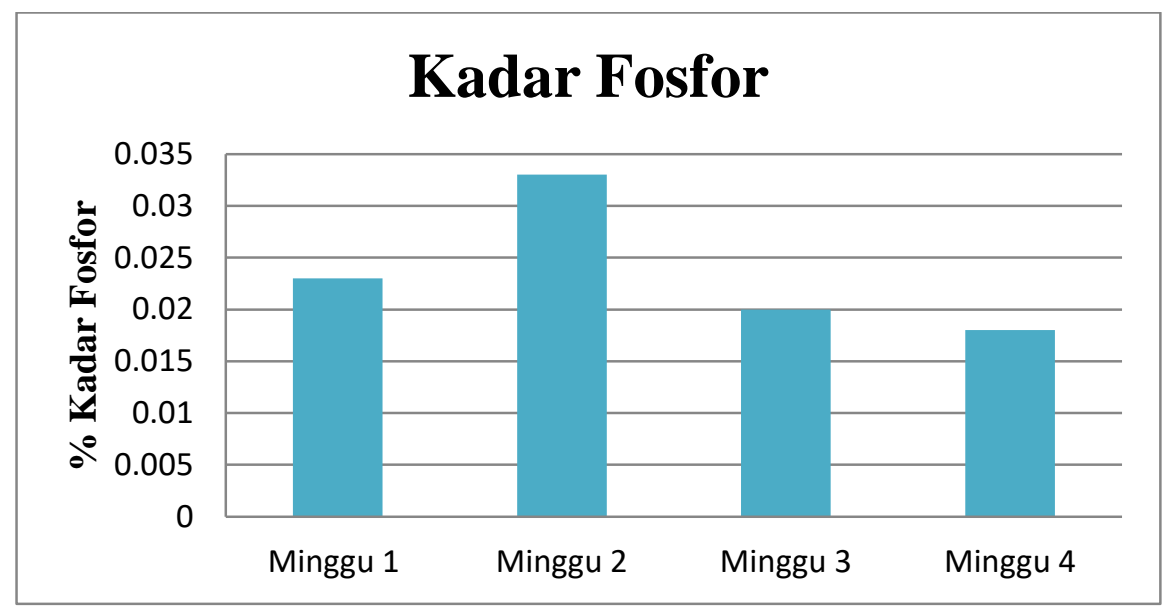

Gambar 3. Histogram pengujian kadar fosfor (\%) pada mikroorganisme lokal kulit kopi

Berdasarkan Gambar 3 terlihat yang paling tinggi adalah minggu 2 yaitu 0.033 , hal ini disebabkan karena semakin lama waktu fermentasi bukan berarti kadar fosfor juga semakin bertambah karena pada proses fermentasi berhubungan langsung dengan mikroorganisme dimana mikroorganisme memiliki fase stationer pada fase ini mikroorganisme mengalami pertumbuhan yang sangat signifikan dan apabila fermentasi dilanjutkan mikroorganisme akan mengalami kematian dan didapat hasil hara fosfor $(\mathrm{P})$ yang lebih sedikit.

Sedangkan kandungan fosfor yang terendah pada perlakuan minggu 1 yaitu 0.023 , minggu 3 yaitu 0.02 , dan minggu 4 yaiu 0.018 . Berbeda dengan lamanya waktu fermentasi sebagian besar dari sampel mengalami penurunan kadar fosfor . Hal tersebut terjadi karena mikroorganisme pengurai fosfor tidak bekerja secara optimum sehingga kadar fosfor makin turun dengan semakin lamanya waktu fermentasi disebabkan oleh adanya udara yang masuk kedalam alat fermentasi ketika pengambilan sampel limbah kulit kopi.

\section{Pengujian Kadar Kalium}

Kalium (K) berperan dalam pembentukan protein dan karbohidrat, pengerasan bagian kayu dari tanaman, peningkatan kualitas biji dan buah. Unsur K diserap dalam bentuk $\mathrm{K}^{+}$, terutama pada tanaman muda (Mulyani, 1994).

Berdasarkan Gambar 4, kadar kalium mikroorganisme lokal kulit kopi yang paling tinggi adalah A2 yaitu 0.035 mengalami kenaikan yang cukup signifikan. Hal ini disebabkan oleh terbentuknya asam organik selama proses penguraian dan menyebabkan daya larut unsur-unsur hara seperti $\mathrm{Ca}, \mathrm{P}$ dan $\mathrm{K}$ menjadi lebih tinggi, dan proses penguraian bahan organik yang dilakukan akan mengurangi kandungan $\mathrm{K}$ pupuk organik cair. Hal ini diduga disebabkan oleh aktivitas mikroorganisme. Mikroorganisme selain merombak kalium juga menggunakan kalium untuk aktivitas metabolisme hidupnya (Notohadiprawiro, 1999). Unsur Kalium juga berfungsi mengatur keseimbangan unsur hara Nitrogen dan Fosfor.

Kandungan kalium yang terendah pada perlakuan A4 yaitu 0.014, pernyataan ini diperkuat oleh Beveridge (1996) yang menyatakan bahwa unsur kalium merupakan unsur utama yang diperlukan oleh semua mikroorganisme untuk pertumbuhan normal. Kadar Kalium cenderung turun dengan semakin lama waktu fermentasi karena dimungkinkan adanya kesalahan ketika pengambilan sampel sehingga udara dapat masuk kedalam alat fermentasi. Mikroorganisme dapat bekerja dengan optimum jika dalam lingkungan kedap udara (anaerob) sehingga apabila ada udara yang masuk kedalam alat fermentasi maka mikroorganisme tidak dapat bekerja dengan maksimal. Hal ini juga diduga karena aktivitas mikroorganisme, dimana mikroorganisme selain merombak kalium juga menggunakan kalium untuk aktivitas metabolisme hidupnya (Notohadiprawiro, 1999). 


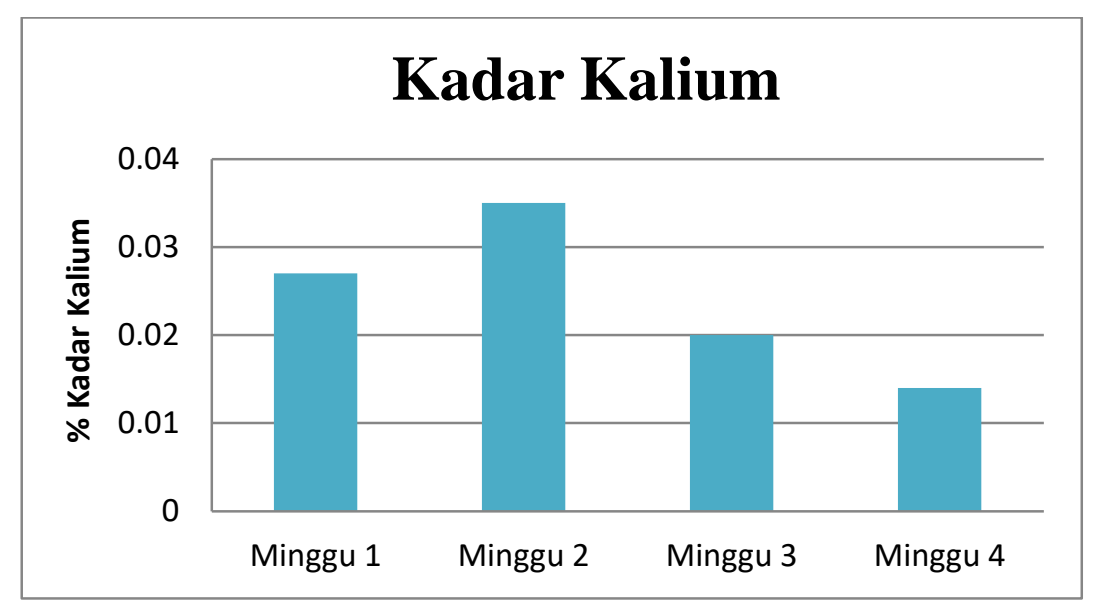

Gambar 4. Histogram pengujian kadar kalium (\%) pada mikroorganisme lokal kulit kopi

\section{Kesimpulan}

Berdasarkan hasil penelitian dapat disimpulkan bahwa rendemen volume MOL tertinggi diperoleh fermentasi pada minggu 4 dengan volume $8,5 \mathrm{ml}$ dan terendah pada minggu 1 dengan volume $5 \mathrm{ml}$. Pengujian kadar nitrogen yang tertinggi berada pada minggu 1, minggu 3 dan minggu 4 dengan nilai $0,039 \%$ dan yang terendah minggu 2 dengan nilai $0,034 \%$. Pengujian fosfor yang tertinggi yaitu minggu 2 dengan nilai 0,033 $\%$ dan yang terendah minggu 4 dengan nilai $0,018 \%$, sedangkan pada pengujian kadar kalium yang tertinggi yaitu minggu 2 dengan nilai $0,035 \%$ dan yang terendah yaitu pada perlakuan minggu 4 dengan nilai $0,014 \%$.

\section{Saran}

Perlu dilakukan penelitian lebih lanjut mengenai identifikasi jenis bakteri yang terdapat di dalam MOL kulit kopi.

\section{DAFTAR PUSTAKA}

Beveridge, M.C.M. 1996. Cage Aquaculture Fishing. Second Edition. News Books. London.

Hadisuwito, Sukamto. 2012. Membuat Pupuk Organik Cair. Agromedia Pustaka: Jakarta.

Hartono.2013. Siaran Pers"Produksi Kopi Nuantara Ketiga Terbesar di Dunia". Diterbitkan oleh: Kementerian
Perindusrian (Kemenperin) tanggal 25 Juli 2013

Hawab, H. M. 2004. Pengantar Biokimia. Banyumedia, Malang.

Mulyani, S. 1994. Pupuk dan Cara Pemupukan. Rineka Cipta. Jakarta.

Ngili, Y. 2009. Biokimia Struktur dan Fungsi Biomolekul. Graha Ilmu, Yogyakarta.

Notohadiprawiro T. 1999. Tanah dan Lingkungan. Jakarta: Direktorat Jenderal Pendidikan Tinggi Departemen Pendidikan dan Kebudayaan.

Purwasasmita, M. 2009. Pemanfaatan Larutan MOL. http://riefarm.blogspot.com/. Tanggal aksess 2 Juli 2012.

Simanihuruk, Kiston dan J. Sirait. 2010. Silase Kulit Buah Kopi Sebagai Pakan Dasar pada Kambing Boerka Sedang Tumbuh. Disampaikan pada Seminar Nasional Teknologi Peternakan dan Veteriner 2010.

Smith, H.P. 1955. Farm Machinery and Equipment. Fourth Edition, New York: Mc Graw-Hill Book Co., lnc.

Suhastyo, A. A. 2011. Studi Mikrobiologi dan Sifat Kimia Mikroorganisme Lokal yang Digunakan pada Budidaya Padi Metode SRI (System of Rice Intensification). Tesis. Sekolah Pascasarjana. Institut Pertanian Bogor. Bogor. 
Suriawiria, U.1996. Mikrobiologi Air. Zainuddin, D. dan T. Murtisari. 1995. Penerbit alumni, Bandung.

Sutanto, Rachman. 2002. Penerapan Pertanian Organik : Pemasyara-katan \& Penerapannya. Kanisius. Yogyakarta.

Yulipriyanto, H. 2010. Biologi tanah dan startegi pengolahannya. Graha Ilmu Penggunaan limbah kopi agroindustri buah kopi (kulit buah kopi) dalam ransum ayam pedaging (Broiler). Pros. Pertemuan Ilmiah Komunikasi dan Penyaluran Hasil Penelitian. Sub Balai Penelitian Klep, Puslitbang Peternakan, Bogor. Hlm. 71-78 Yogyakarta. 